\title{
A STUDY OF ISLAMIC AND ARAB MARKETS' ROLE IN REVITALIZING URBAN SPACES
}

Mohamed Yasser Lotfy

Abdullah Soliman

M Alaa Mandour

\author{
Assistant Prof of Architecture \\ Helwan University
}

Lecturer Arab Academy

Prof. of Architecture and Urban Design, Helwan University

Email: alaa_mandour2004@yahoo.com

Received: August $10^{\text {th }}$ 2015; Accepted: November $4^{\text {th }}$ 2015; Available Online: December $31^{\text {st }} 2015$

DOI: http://dx.doi.org/10.18860/jia.v3i4.3026

\begin{abstract}
Market places have occupied a major role in most cities around the world, being a site for more than just economic interactions, but rather a cultivating agent for social and cultural growth. The Arab and Islamic cities have a proud history of market places, most of the times being the main core of the city, with urban development encompassing it, and till the present day market places are in the heart of most communities. The modern city brought with it a devaluing of the traditional market places, making it a tourist attraction as in the case of "khan el Khalil",or leaving it to rust like "bab el louq" market. Those markets while playing a big role historically, modern city planning moved the services and markets into other form, thus becoming less important, abandoned, or even demolished at cases. The issue at hand deals with how the contemporary urban planning affected market places, with emphasis on closed markets (Bab el-louk)which can be said to be the successor of the ancient Bazaar or Wekala. Bal el-Louk market was once in the heart of Cairo and vital part of its community life, but now the market after more than a 100 years, is in ruins, but hope is not yet all lost, since the market can still be revived and revitalized. To tackle this issue a combination of comparative and field studies must occur. On the one hand, comparative studies with markets in the US or closed markets in European cities such as Paris or Copenhagen would be done to find the necessary elements and goals that would make those markets vital, and the necessary steps to revitalize our own forgotten markets. The other study would have to deal with the current condition of bab el louk market in Cairo, finding out the reason behind its demise, the owners and users feedback on said market, and the opportunities for change. With the results of the studies, general recommendations would be made for the revitalization of the Egyptian marketplaces, using an urban framework that would lead to those markets be available for costumers again and back to playing their major cultural and social rule.
\end{abstract}

Keywords: Islamic Souq, Malls, Revitalizing, Traditional market, Bab el louq

\section{Introduction: The Historical Role of Market Places}

A marketplace is the regular gathering space for people to shop, socialize and interact with one another. Markets have existed as long as humanity did, moving from one form to another. During the last half of the $20^{\text {th }}$ century the role of the traditional marketplace have declined, making way for the mega shopping malls, or even for online shopping, leaving the old marketplaces to decay.

\section{The Egyptian Market Place}

Egypt had a long history of Market places, and it can be argued that the current marketplace is the successor of the old Islamic "bazar" or "wekela". This can be traced back to old Cairo, where the street market was the main element and center of the city, such as "Moaz Street", and supporting it a large number of "wekala", "khan", or "bazar".

Furthermore, During the Khadival era, Egypt, and especially Cairo, have seen a rise in the number of closed markets, including "Bab el louk" 
market which this paper revolve around, as well as "al attaba" market, "Al-Azhar" market, among others.

Unfortunately, those markets have lost their role over the past year, but they do still carry the potential for revival and through it a complete integrated process of revitalizing the community that benefit from it the most, along with open and public spaces.
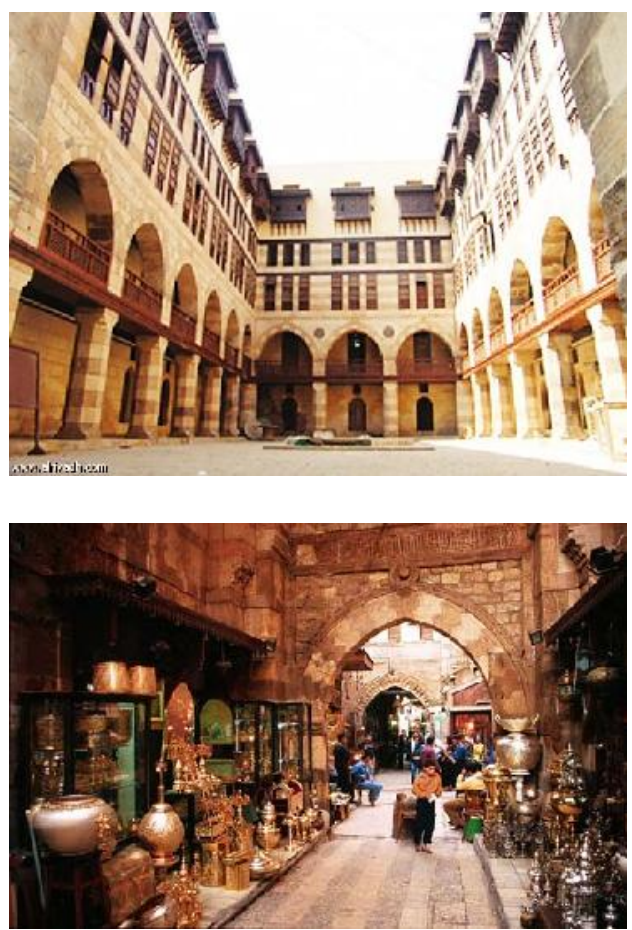

Figure 1\&2. Bab El-louk Market in the heart of the khadeval Cairo, overlooking tahrir square [1].

\section{Bab El Louk Market-A Case Study}

Overlooking Tahrir square is a large turn of the century building with a large central arch. The inscription above the central archway reads "Marche de Bab el Louq 1912" in French and “ " in Arabic [2]. The interior is a beautiful, intact, original iron truss roof not unlike what you see in turn of the century train stations. The floor plan is a grid of shops selling (or that once sold) vegetables, meat, poultry, dairy, etc. The market was once truly central to the community and was well frequented with shoppers. There is also a gallery on the second level that borders the perimeter with more shops. The gallery is reached by the original iron stairs and railing, although there has also been some modifications added. It seems as though some squatters have moved into the rooms on the upper floor which overlook the streets outside. Today the market is in a decay and is little frequented by shoppers who shop elsewhere. Many of the shops and shop spaces are either closed or vacant and only a few vendors are present but their livelihood depends on this place.

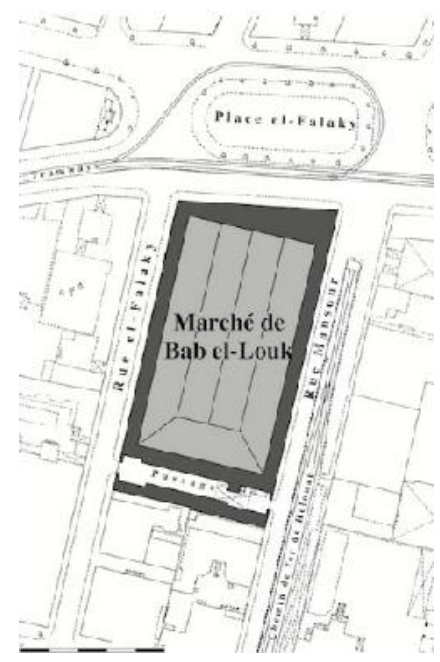

Figure 3. . Bab El-louk Market in the heart of the khadeval Cairo, overlooking tahrir square. (Garret P. , 2010)

\section{The Market's Urban Context}

The Market is located in downtown Cairo, in close proximity to Tahrir square and overlooking Falki square. The Surroundings of the Market had once been a vital lively part of downtown, due to the tram station that was used to be in the square, which now have been turned into a parking garage.

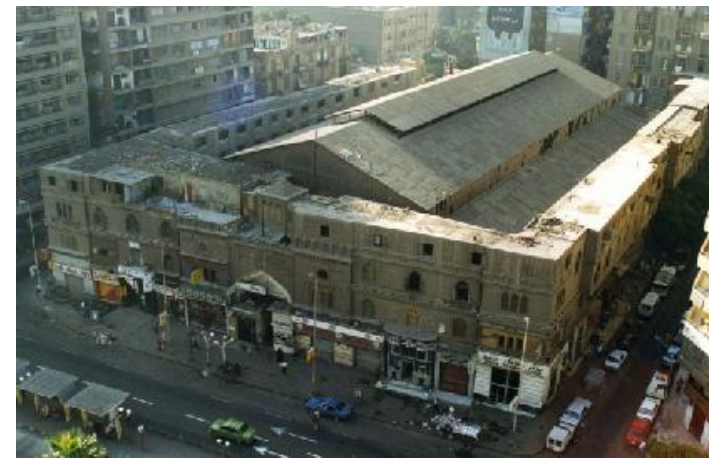

Figure 4. The marketplace in downtown, close to Tahrir square, has dwindled into a decaying state[3]. 
As a result, the market lost its value with time, and is now in decay after once being a vital part of Cairo.

\section{Morphological Study of the Market}

On the 1st of May 1912, the market was officially inaugurated and open to the public. It was the conception of an Egyptian Jewish engineer and banker; Joseph AslanCattaui. It was constructed in a strategic location next to Cairo's tramway network and railway line to Helwan, which was vital at the time, the elementswere key in providing a huge demand for the new market [3].

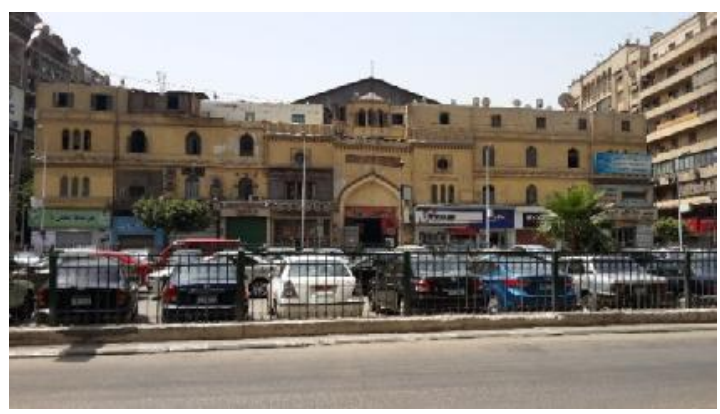

Figure 5. Bab El-louk Market in the heart of the khadeval Cairo, overlooking tahrir square[1].

The initial design composed of a hall measuring forty seven meters wide by eighty four meters long, the market's spaces proved too large to occupy. In 1925 transformation of the market's south end shops lying just before the service path into a car park went underway until completion in 1930. The modification consequently blocked direct access from the service path into the building[3].

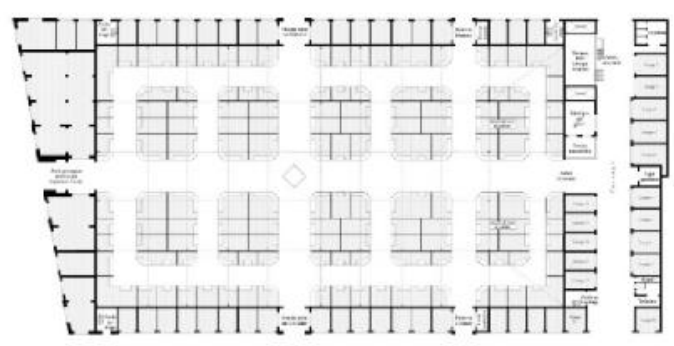

Figure 6. The original plan of the market consisted of an iron grid pattern with main corridor in the middle, intersecting with a number of secondary corridors[3].

In 1942 the new Egyptian owner; Hussein Ahmed Issa led a second phase in the market's morphology with plans for constructing a second floor for the market completed in 1948. By that time the market was vibrant and successful due to effective management, regular cleaning schedules, and presence of security personnel are considered to have had an important role[3].

By 1952 the revolution came and with it the market's decline. Closing the ice factory in 1954 alongside rent deductions and a new rental law, and in the late 50s the market witnessed a rise in shop unauthorized expansions on market space.
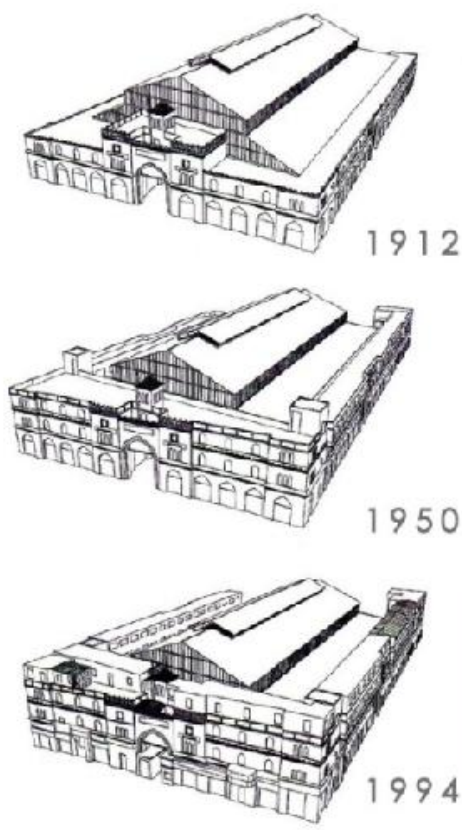

Figure 7. Morphological progression of the Market façade[3]

During the 70s, an increase of shoe trade led to shoe shops taking over the first floor, and as a result an addition of a third floor to the market then took place in 1970.

But the pivotal point in the decline of the Market was during the 80s. The Changes in Cairo's transport infrastructure took place around theat time, including Bab El-Louk's train station that was removed as part of demolition works required prior to the construction of Cairo's Metro. As a result, a noticeable decrease in customers happened. Shops and stores movedbut kept their units as storage space.

Another important part of the market's morphology happened due to the government's plans to move major services out of Cairo's city center. A new market outside Cairo was constructed, El-Obour market. Plans were 
underway for tradesmen and shop owners to move their goods and leave the old market.

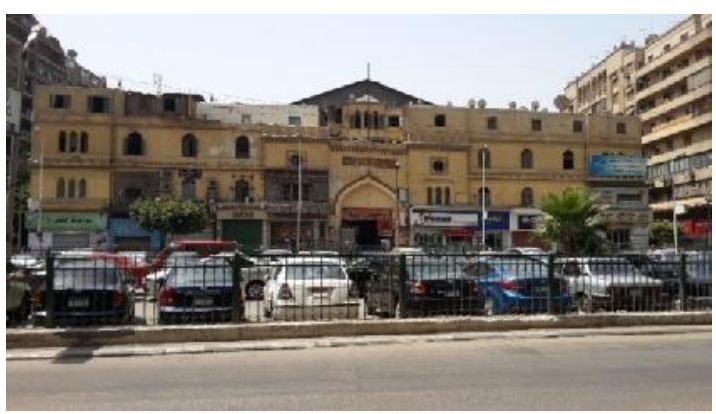

Figure 8. The marketplace in downtown, close to Tahrir square, has dwindled into a decaying state

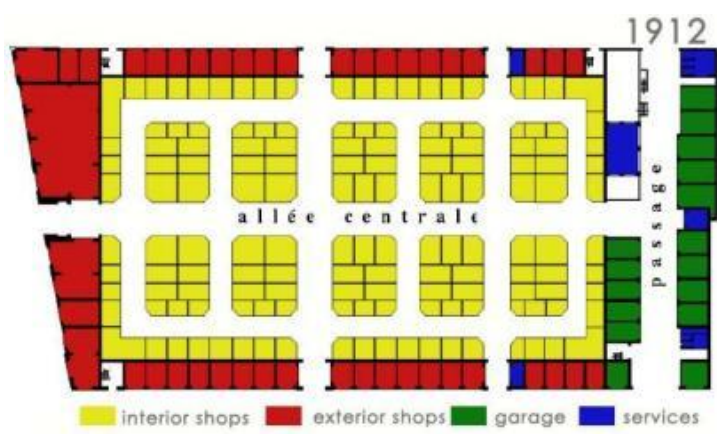

Figure 9. The original plan of the market consisted of an iron grid pattern with main corridor in the middle, intersecting with a number of secondary corridors[3].

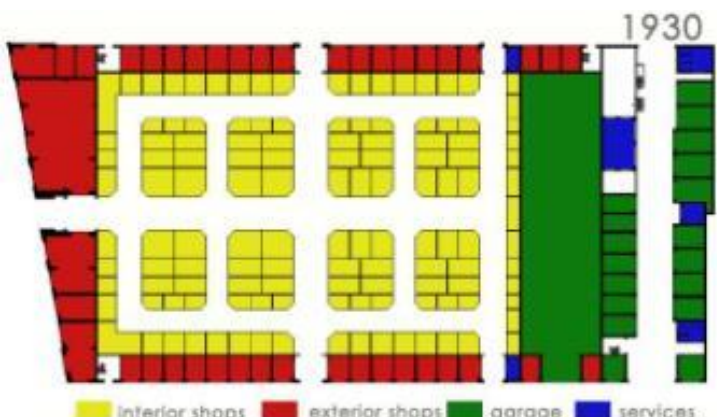

Figure 10. The outside/inside shops remains the same, but the space allocated to walking was reduced to make space for thegarage. Thus suppressingaccess to thepassage and its functions: deliveries, storing cartsseats, access to thecellarsand services [3]

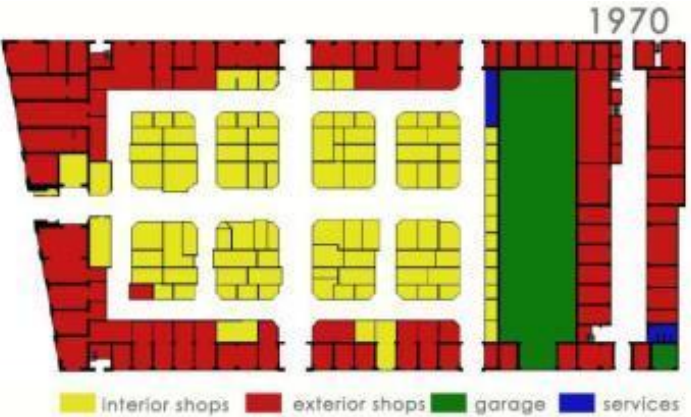

Figure 11. After the creation of the garage,the passagebecameseparated fromthe activity of the market.Also the expansion of the exterior shops, along with the main path's shops had started around this time[3]

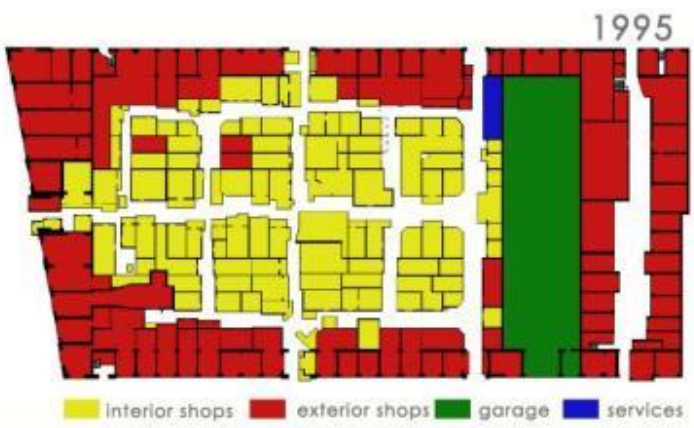

Figure 12. During the $90 \mathrm{~s}$, theextensionof external shops continued inside the market, and the enterior shop expandedbeyondthemain paths.

AlsoPublicservices have diminished, apart fromprayerspacethat hasbeen created [3]

\section{The Current Conditions}

The market's condition have been deteriorating rapidly over the past decades. This decay is characterized by an unauthorized expansions both in the interior and exterior shops, thus the pathways are now narrower and harder to use.

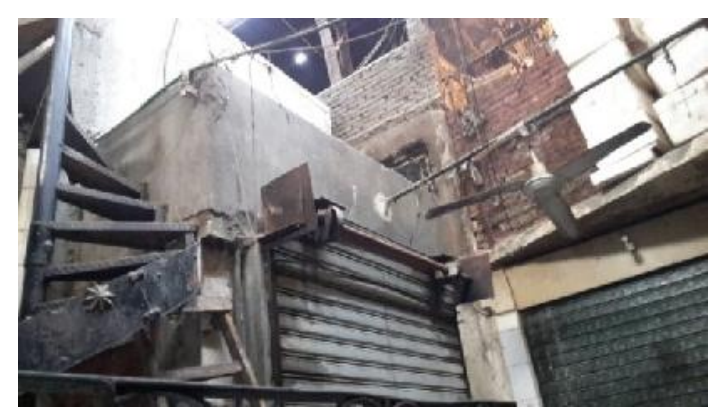

Figure 13. Unoccupied shops in the ground floor 


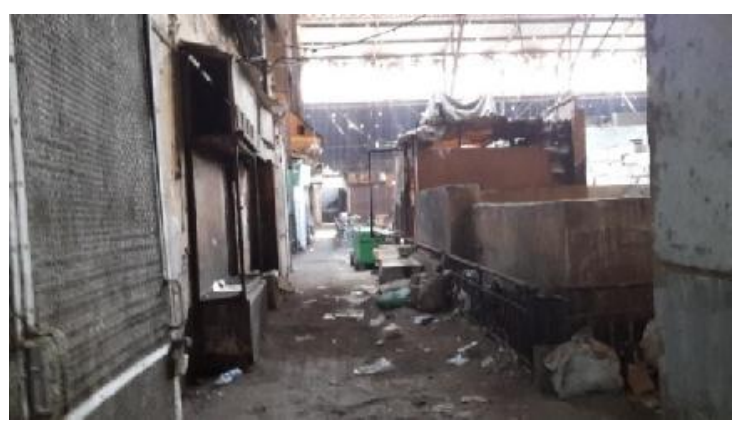

Figure 14. Unoccupied shops in the first floor

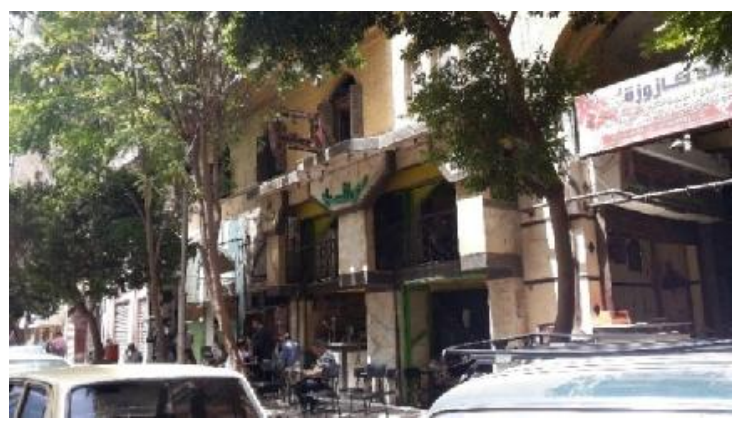

Figure 15. The exterior shops have been mostly altered to be cafes

Another side of the decay is the urban one, as currently the market no longer plays a part in the larger urban community, even though markets have been historically know as a revitalizing agent.

The occupancy of the market have dwindled as well, among the 181 shops in the ground floor, 42 shops or up to $25 \%$ are no longer occupied. As for the rest of the shops, they work with a minimum capacity, serving less numbers than they used to be.

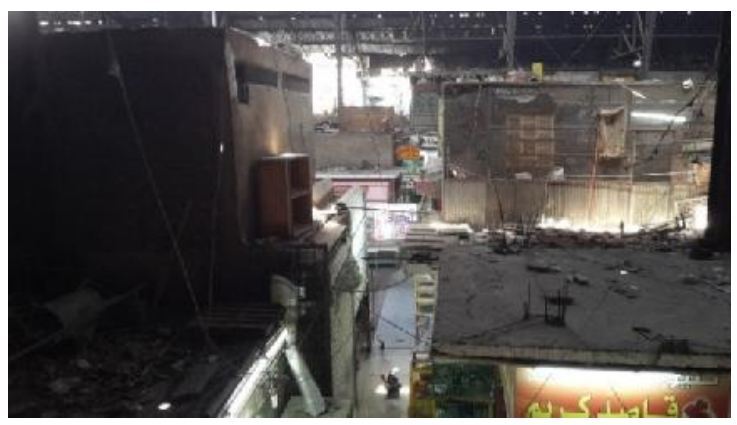

Figure 16. The deteriorating first floor and overlooking the random expansions done by tenants.

The second floor occupancy rate is even worse, out of the 95 shops in that floor, $45 \%$ of shops are out of business, with only 55 still open but with little to no business, or in most cases have been turned into storage areas for the owner who moved their business elsewhere.

Also, the exterior elevations have been altered dramatically due to the change in use, as for now a large number of those shops have turned into local cafes or electronic shops, along with travelling agencies and pharmacies.

Most of those issues can be tracked back to rent control that made tenants more powerful than the owner, and the change in the urban context leading to the market being of less importance.

\section{Revitalization Approach and Methods}

Market places have always been about much more than shopping. Retail is an important part, but people also come for many other reasons, with a strong social factor too, since the market is often the place where local people come together to meet friends and join in community activities. It can provide a setting for shared experiences, and be a focal point of local identity, community pride, and common heritage and values [4].

Revitalizing marketplaces focuses mainly on the revival and strengthen the community and social role of the marketing. That can be achieved through a number of elements such as streetscape, open space, pedestrian areas...etc.

\section{Goals of the Revitalization Process}

\section{Enable people to move around better}

This can be done by rebalancing the Market Quarter to focus on people, street activities and businesses instead of motorizedvehicles. This will make any Old Market an important destination for people to get off public transport and shop or walk through to the City Centre[5].

\section{Improve the attractiveness of the area}

The Market's unique local heritage must be enhanced by promoting the identification, protection and reuse of important local assets alongside listed buildings. Also, new buildings can respond to the character of Old Market Quarter. Shop fronts along the high street must respect the history and character of the area whilst ensuring economic viability.

Encourage more employment, better shops, housing and local facilities

These will contribute to a balanced and independent community. Flexibility of uses must be encouraged within the designated Local Centre 
and ensure the retention of active uses at Ground Floor level. Furthermore must safeguard employment in the area and create opportunities for new businesses[5].

\section{Protect and enhance open spaces}

New developments should enhance adjacent streets and open spaces by improving natural surveillance, lighting and pedestrian access.

\section{Elements used to revitalize public spaces}

\section{Sidewalks}

Sidewalks serve a social function. They are where you might meet an acquaintance you haven't seen in years, or stop to finish a conversation that you began the day before. Sidewalks also give you a chance to interact with people who you don't know in all kinds of different encounters and activities. As you make your way along the sidewalk, you're doing more than just going about your business. You're participating in the life of your community[6].

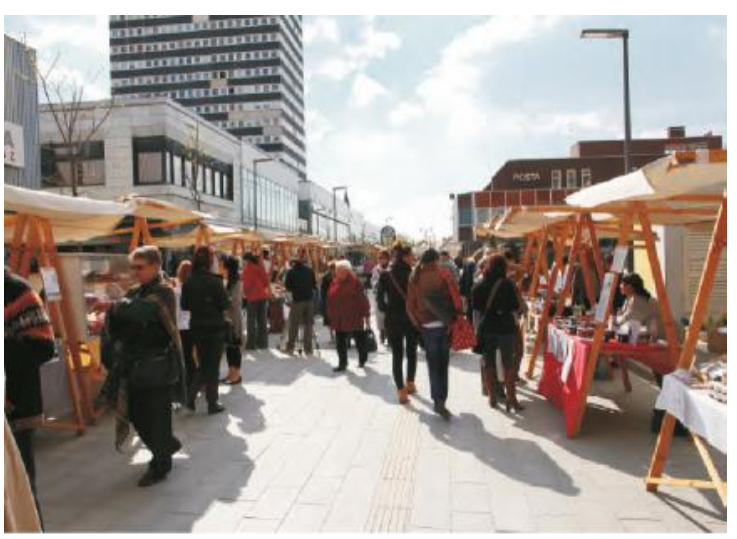

Figure 17. Sidewalks are a site of social interactions [6]

\section{Squares and Other Gathering Places}

Squares are a center for concerts, holiday celebrations, dances, speeches, commemorations and all kinds of other community events. It is also where people come to relax, to meet their friends, to stroll with their sweethearts, to hang out and. Modern plazas and "vest-pocket parks" can serve the same purpose, when they're designed so that people can sit comfortably, move around with ease and be able to enjoy what's going on there.

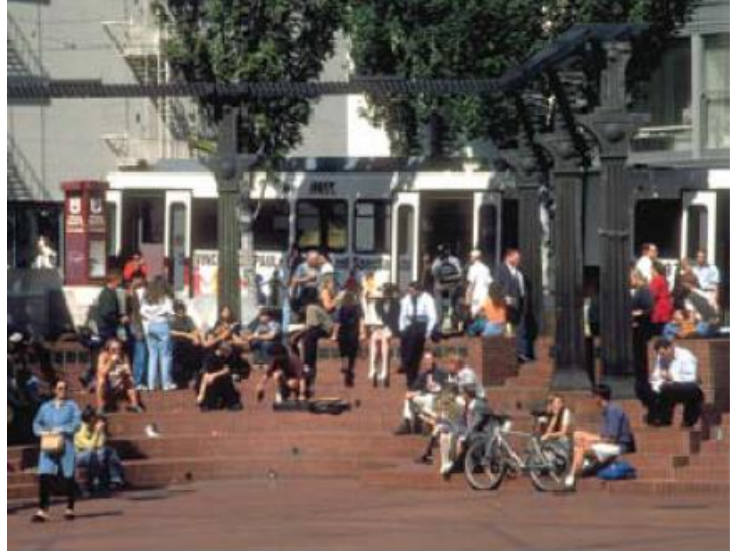

Figure 18. Squares are the center of the community activates and can help revitalize market places[6]

Vendors

The success of public markets reveals a favorite human pastime, shopping-the kind of shopping that involves small, sometimes spontaneous, purchases in public spaces. Vending carts and stands, when they are carefully designed and located according to community needs and specific guidelines, can provide this type of intimate shopping experience while enhancing a place's friendliness and character[6].

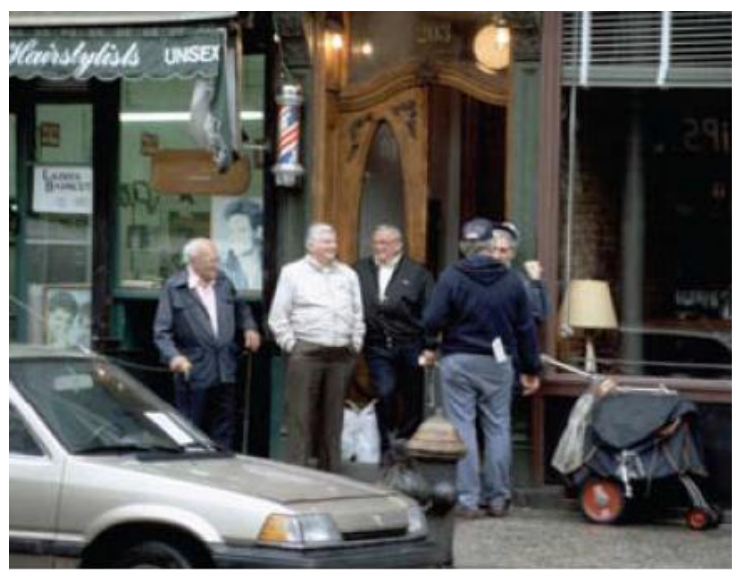

Figure 19. Vendors can work as a way of revitalizing a public space if used and regulated properly[6]

\section{Amenities}

Amenities are supporting elements that makes using the public space available easier, those include; seating's, signs, public art, vegetation and any elements that can enhance the space. 

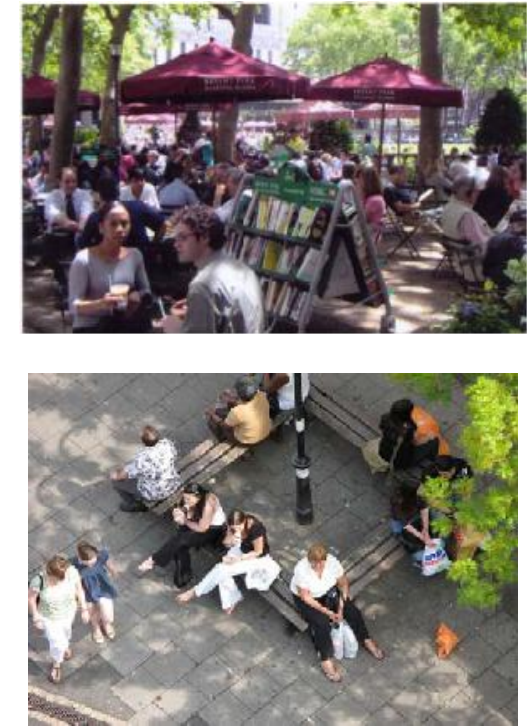

Figure 20. Amenities make public spaces more accessible[5]

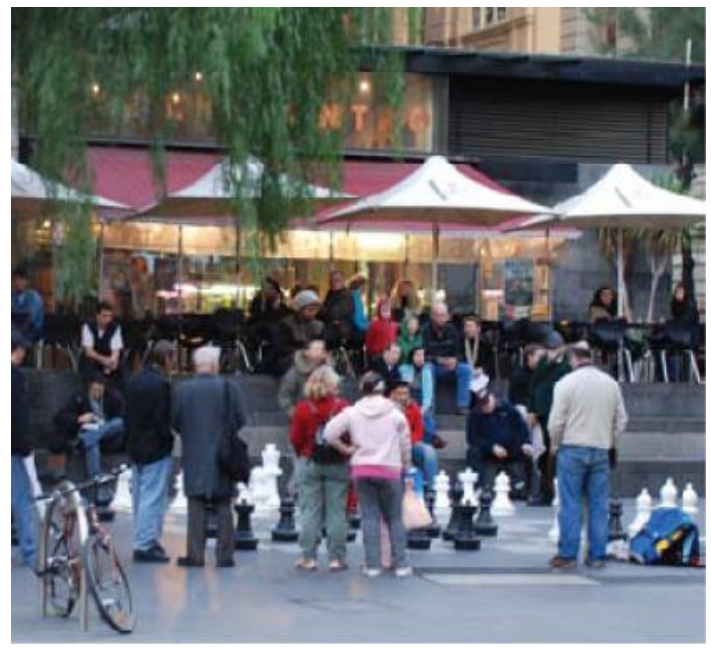

Figure 21. Gathering spaces can work as a place for events and thus revitalizing the space [5]

\section{Celebrations and Gatherings}

Live performances, like jazz, rock and folk concerts, classical-music series, dramatic presentations, magic shows, even lectures and demonstrations, also bring people back to public spaces to share the collective enjoyment and connection that has always enriched communities[6].

\section{Maintenance and Management}

Once physical improvements have been made to place, they need to be maintained. They need to be cleaned and scrubbed and shined. If they break, they need to be repaired, and if they show wear, they need to be spruced up. It also helps to have a visible presence on hand to help promote a place's security. These are the key elements of any management program, which usually involves joint funding and cooperative efforts of the private sector and city governments.

\section{Conclusion}

While the issue of deteriorating marketplaces is a tricky subject to handle and can be dealt with by some through demolishing or other methods that doesn't take into account the historical and social value of the market place itself, revival or revitalizing could be the answer for the issue rather than using excessive force.

Egypt had seen its share of deteriorating marketplaces even though it does have a historical root in the Egyptian society from old Islamic era, and probably earlier. Markets that had been thriving in the turn of the $20^{\text {th }}$ century have now became abandoned, or turned into an entirely different use as what happened with "Al-Attaba market".

"Bab El-Louk" on the other hand, is one of the few surviving Markets that were constructed in the Khadival era. It's in decay but it's not beyond hope, and the Market is still functioning till today.

"Bab El-Louk" does mainly suffers from the lack of management, whichled to unauthorized alterations and expansions and even the change from the original use for most of the exterior shops.

On an urban scale, "Bab el-Louk" originally had what seemed to be the perfect location in the heart of Cairo, just next to Tharir square and in front of the tram station at the time. Thus making the open space surrounding the market a site thriving with social activities. But with the change in the transportation system, along with the decay already in place due to rent laws and management issues, the market started losing its previous glory.

To revitalize "Bab el-Louk" market, a holistic approach must be in place that fixes the physical issues with the market, but without neglecting the urban space and fabric surrounding the market. Since without an attractive public space, the market would still not be frequented as it once was.

\section{References}

[1] P. Garret, Appropriation et transformation d'un modele importe en Egypte: le cas du marche de Bab el-Louk au Caire. 2010.

[2] C. Observer, Cairo's central markets. 2011. 
[3] P. Garret, “Appropriation et transformation d'un modèle importé en Égypte: le cas du marché de Bab el-Louk au Caire. [Appropriation and transformation of an imported model in Egypt : the case of Bab el Louk market Cairo]," Les Cahiers du Réseau Architecture/Anthropologie, 1996. [Online]. Available: http://hal.archivesouvertes.fr/docs/00/46/61/02/PDF/Pascal GarretCaireBabelLouk.pdf. [Accessed: 26May-2014].
[4] G. Shapps, Re-imagining urban spaces to help revitalise our high streets. 2012.

[5] S. Williams, Old Market Quarter Neighbourhood Development Plan. 2013.

[6] F. Kent, Streets as Places. 2008. 